\title{
EFFECT OF ULTRA HIGH TEMPERATURE PROCESSING ON LIPIDS OXIDATION IN MILK-FORTIFIED WITH SOME MINERAL ELEMENTS
}

\author{
Atallah Hameed Abdulghani \\ Department of Food Science \\ College of Agriculture \\ Tikrit University
}

\author{
Mahmood Younis Ali \\ Department of Food Science \\ College of Agriculture and Forestry \\ Mosul University
}

E-mail: atallah.abdulghani@yahoo.com

\begin{abstract}
The hypothesis of the present study was that the Ultra-high temperature (UHT) processing of fluid milk-fortified with $\mathrm{Zn}, \mathrm{Fe}$ or $\mathrm{Mg}$ individually might change the perception of milk flavor as compared to normal UHT milk without fortification. Samples of fortified milk with zinc, iron and magnesium have been processed by a bench-top UHT plant $\left(145^{\circ} \mathrm{C} / 6\right.$ s) and filled into transparent polyethylene terephthalate containers. The milk samples were stored in closed incubator at $30{ }^{\circ} \mathrm{C}$ for 60 days without exposing to light. At 10 and 30 days intervals, the samples were assessed for TBA test and sensory evaluation respectively. The main concern of this work was to evaluate the effect of UHT processing on the level of oxidation by both chemical and sensory evaluation of the fortified milks. Results showed that the values of TBA test increased significantly $(\mathrm{p} \leq 0.05)$ at the end of the storage life $\left(60 \mathrm{~d} / 30{ }^{\circ} \mathrm{C}\right)$. Sensory evaluation of fortified milks with $\mathrm{Zn}, \mathrm{Fe}$ and $\mathrm{Mg}$ showed miscellaneous results.
\end{abstract}

Keywords: Sensory evaluation of UHT milk, TBA, Fortification, Zn, Fe, Mg.

Received: 13/3/2013., Accepted: 6/5/2013.

\section{INTRODUCTION}

López-Fandiño and Olano (1999) observed that proteolysis and lipolysis are cofactors in determining the shelf-life of Ultra-high temperature (UHT) processed milk. Lipases of some psychrotrophic bacteria, existed in cold raw milk, may survive UHT treatment and then can play an important role in lipolysis, and then the oxidation of fatty acids during storage term.

Oxidized flavor is a result of many reactions involving free radicals, for instance, riboflavin being light sensitive absorbs UV and converts the energy absorbed into very effective compounds (Min and Boff, 2002). Many short-chained aldehydes and ketones may be generated due to the free radicals' interactions unless some other compounds such as anti-oxidants interfere and stop the reactions (Solano-Lopez et al, 2005). The generated products contribute to the stale flavor in the UHT milk (Perkins et al. 2007). Some factors enhance the oxidation reactions in UHT milk among which are light, iron, and keeping temperature. On the other hand, some factors inhibit the reactions such as sulfhydryl compounds which can inhibit oxidations that proceed by a free radical mechanism. (Shipe et al, 1978, Smet et al., 2009, van Aardt et al., 2005). Homogenization has both effects; it inhibits formation of oxidized flavor components of off-flavor, but enhances the development of the light-activated ones (Shipe et al., 1978).

The research is a part of the Ph.D. thesis of the $1^{\text {st }}$ researcher. 
Milk storage leads to physico-chemical changes in milk. Being temperature dependent, these changes may influence milk stability (Gaucher et al., 2008). The development of any off-flavors is noticeable in milk because it has naturally mild, slightly sweet flavour (Gandy et al, 2008). Moderate storing temperatures $\left(30-35^{\circ} \mathrm{C}\right)$ after UHT processing, may help some survived bacterial spores to restore its activity. Also, thermal stable enzymes may cause a serious problem to UHT milk, leading to undesirable sensory alterations or objectionable flavours (Choi and Jeon, 1993 Hayes et al., 2002, Muir, 1990, Tondo et al., 2004).

Milk is a good vehicle for delivering supplemental transition metals because of its consumption worldwide. But these metals, especially iron, may cause "oxidized" flavors. Therefore, stability and palatability of the dairy products must be maintained in fortified milk (Hegenauer et al, 1979).

The well-known Thiobarbituric acid (TBA) assay is adopted by many researchers to quantify lipid oxidation in milk. It can be conducted to complement sensory evaluations in monitoring the level of oxidative deterioration in milk and dairy products (King, 1962, Hegenauer et al, 1979).

The hypothesis of the present study was that the fortification of fluid milk with some mineral elements prior to UHT processing might alter the flavor of the milk in comparison with normal UHT milk.

\section{MATERIALS AND METHODS}

Source of Milk: Samples from different batches of homogenized and pasteurized whole milk were collected from Parmalat (Queensland, Australia). Average concentrations of the main components of the collected milk samples were shown in (Table 1).

Table (1): Average concentrations of some main components of the processed milk.

\begin{tabular}{|c|c|c|c|c|c|c|c|}
\hline Item & Fat & $\begin{array}{c}\text { Total } \\
\text { solids }\end{array}$ & $\begin{array}{c}\text { Solid } \\
\text { Non- } \\
\text { Fat }\end{array}$ & $\begin{array}{c}\text { True } \\
\text { proteins }\end{array}$ & Caseins & $\begin{array}{c}\text { Whey } \\
\text { proteins }\end{array}$ & Lactose \\
\hline Mean* & 3.85 & 12.54 & 8.70 & 3.24 & 2.66 & 0.58 & 4.67 \\
\hline S.D. & 0.14 & 0.37 & 0.25 & 0.10 & 0.08 & 0.02 & 0.12 \\
\hline
\end{tabular}

* Average of 8 different samples of homogenized whole milk.

Mineral Elements: Analytical grade of sodium citrate and sulphates of Zinc, Iron and Magnesium used were obtained from Sigma-Aldrich, Inc. (Australia). Depending upon the approximate average of Recommended Dietary Intake (RDI) for adults in Australia (Australian Government, 2006), fifty percent of RDI for fortified milk samples were prepared (Table 2). The approximate RDI values of Zinc $\left(\mathrm{T}_{1}\right)$, Iron $\left(\mathrm{T}_{2}\right)$ and Magnesium $\left(\mathrm{T}_{3}\right)$ adopted were 16,8 and $320 \mathrm{mg} /$ day respectively. Magnesium samples were prepared taking in consideration the original amounts of magnesium in normal bovine milk ( 120 mg/l) (Walstra et al., 2006). Anhydrous sodium citrate was 
added to magnesium samples to prevent fouling in UHT plant caused by the coagulation of milk proteins due to high concentration of free magnesium.

Fortification: Accurately weighted amounts of all salts were thoroughly dissolved in adequate amount of distilled water $(25 \mathrm{ml} / \mathrm{litre}$ milk). Fortified whole milk samples were prepared by adding of the dissolved salts into the milk and mixed gently shortly before heat treatment. Only $25 \mathrm{ml}$ of distilled water was added to the control milk sample $\left(\mathrm{T}_{0}\right)$.

Table (2): Elements' concentrations used in preparing UHT processed milk-fortified samples $(\mathrm{mg} / \mathrm{l})$.

\begin{tabular}{|c|c|c|c|c|c|c|}
\hline $\begin{array}{c}\text { Fortified milk, } \\
\text { with }\end{array}$ & Code & $\begin{array}{c}\mathrm{RDI} \\
(\sim \% 50)\end{array}$ & $\begin{array}{c}\mathrm{ZnSO}_{4} \\
\mathrm{H}_{2} \mathrm{O}\end{array}$ & $\begin{array}{c}\mathrm{FeSO}_{4} \\
7 \mathrm{H}_{2} \mathrm{O}\end{array}$ & $\begin{array}{c}\mathrm{MgSO}_{4} \\
\text { Anhyd. }\end{array}$ & $\begin{array}{c}\mathrm{Na}_{3}\left(\mathrm{C}_{6} \mathrm{H}_{5} \mathrm{O}_{7}\right) \\
\text { Anhyd. }\end{array}$ \\
\hline Control & $\mathrm{T}_{0}$ & - & $/$ & $/$ & $/$ & $/$ \\
\hline Zinc & $\mathrm{T}_{1}$ & 8 & 21.94 & $/$ & $/$ & $/$ \\
\hline Ferrous & $\mathrm{T}_{2}$ & 4 & $/$ & 19.89 & $/$ & $/$ \\
\hline Magnesium* & $\mathrm{T}_{3}$ & 40 & $/$ & $/$ & 197.9 & 322.3 \\
\hline
\end{tabular}

* Original concentration of Mg was taken in consideration; only $40 \mathrm{mg} / \mathrm{l}$ was added to make a total of $160 \mathrm{mg} / \mathrm{l}(\sim \% 50 \mathrm{RDI})$.

UHT Processing: UHT processing is conducted by a bench-top UHT plant at School of Agriculture \& Food Sciences (SAFS) in University of Queensland/ Australia, using indirect (tubular) heating system. The holding times in the preheating and high-temperature sections were $8 \mathrm{~s}$ at $95^{\circ} \mathrm{C}$ and $6 \mathrm{~s}$ at $145^{\circ} \mathrm{C}$, respectively. After heat treatment the samples were cooled to $\leq 35^{\circ} \mathrm{C}$ in $25 \mathrm{~s}$ in a tubular water-jacketed cooler. The flow rate was maintained at $150 \mathrm{ml} / \mathrm{min}$. The UHT-processed milk samples were filled aseptically into Gamma ray pre-sterilized Polyethylene terephthalate (PET) containers in a laminar flow cabinet sterilized by Ultra-violet light (UV) shortly before processing and filling. The capacities of the containers used for filling were 100 and $500 \mathrm{ml}$ for chemical and sensory evaluation tests respectively. All samples were compared to neither treatment sample of UHT milk (control, $\mathrm{T}_{0}$ ) plus 25 $\mathrm{ml}$ of distilled water per each liter of milk and was processed in the same manner. UHT milk samples were stored at $30^{\circ} \mathrm{C}$ for 60 days.

Sensory evaluation: All samples were stored in a fridge $\left(4^{\circ} \mathrm{C}\right)$ for $10-14$ days before evaluation. Sensory evaluation has been done by ten trained panellists in two different sessions using Triangle Test in which the panellists were presented the samples in a balanced random order. The minimum number of correct responses required for significance at level (0.05) for the corresponding number of assessors (10) is equal to or greater than the value (7) (British Standard BS ISO, 2004, Meilgaard et al, 2007).

Chemical analysis: TBA test was carried out for fortified samples as described by King (1962). Results were shown as Optical Density (OD) value and the concentration of the TBA reactive substances (TBARS) $(\mathrm{nmol} / \mathrm{ml})$. All chemicals were purchased from Sigma-Aldrich, Inc. An average value of four replicates was recorded for each test. A standard curve equation was obtained by using 1,1,3,3 Tetraethapropane (TEP) 
as reactive substance with concentrations between $0-1 \mathrm{nmol} / \mathrm{ml} \quad(y=0.119 x-0.0007)$. The results were compared with the findings of King (1962) which is shown below in Table (3).

Table (3): The relationships between organoleptic test and TBA values*.

\begin{tabular}{|c|c|c|}
\hline $\begin{array}{c}\text { Flavor } \\
\text { Score }\end{array}$ & Description & $\begin{array}{c}\text { Range of Optical } \\
\text { density (532 nm) }\end{array}$ \\
\hline 0 & No oxidized flavor & $0.010-0.023$ \\
\hline 1 & Questionable to very slight & $0.024-0.029$ \\
\hline 2 & Slight but consistently detectable & $0.030-0.040$ \\
\hline 3 & Distinct or strong & $0.041-0.055$ \\
\hline 4 & Very strong & $>0.056$ \\
\hline
\end{tabular}

* King (1962)

Statistical analysis: The complete randomized design (CRD) was used. Statistical differences were determined by Statistical Analysis System (SAS), Version (2002) using Duncan's multiple range test at $(\mathrm{p}<0.05)$.

\section{RESULTS AND DISCUSSION}

Sensory evaluation: Table (4) shows the results of the sensory evaluation of fortified milks compared to control UHT milk. In the beginning of the study (d 0$)$, results showed insignificant differences in both replicates between each fortified milk and the control milk according to Triangle test. Hence, most of the panelists were not able to pick up the odd milk samples. In other words, neither UHT processing nor fortification of milks individually with zinc, iron and magnesium had no direct effect on milk Taste. After 30 days, the stored milk samples at $30{ }^{\circ} \mathrm{C}$ showed different attitudes. In $1^{\text {st }}$ replicate the panelists could only perceive magnesium milk significantly. But in the $2^{\text {nd }}$ replicate they were able to distinguish zinc and iron fortified milks significantly too. At last sensory test, the results were miscellaneous; only UHT milk-fortified with magnesium was not perceivable in both replicates.

TBA test: Data in Table (5) are shown as OD and TBA reactive substances (TBARS). TBA results show that the processing affected significantly all treatments of the fortified milk samples $\left(\mathrm{T}_{0}, \mathrm{~T}_{1}, \mathrm{~T}_{2}\right.$ and $\left.\mathrm{T}_{3}\right)$ at all time intervals $(\mathrm{d} 0,10,20,30,40$, 50 and after $60 \mathrm{~d}$ ). UHT processed milk-fortified with zinc has shown similarity with control milk in oxidation levels along storage life $\left(60 \mathrm{~d} / 30^{\circ} \mathrm{C}\right)$ (Figures $\left.1 \& 2\right)$. By contrast, ferrous milk $\left(\mathrm{T}_{2}\right)$ showed dissimilarity in TBA values $(\mathrm{p} \leq 0.05)$. The attitude of magnesium milk $\left(\mathrm{T}_{3}\right)$ was closer to ferrous' $\left(\mathrm{T}_{2}\right)$ except after $60 \mathrm{~d}$ of storage at which the values were significantly different. Also, data of $\mathrm{T}_{3}$ have indicated an insignificant rise in TBA values for the first three tests compared to the control milk $\left(\mathrm{T}_{0}\right)$. 
Table (4): Sensory evaluation results for the Taste of UHT processed whole milk fortified with $\mathrm{Zn}, \mathrm{Fe}$ and $\mathrm{Mg}$ during storage $\left(60 \mathrm{~d} / 30^{\circ} \mathrm{C}\right)^{\mathrm{a}}$.

\begin{tabular}{|c|c|c|c|c|c|c|c|}
\hline \multirow{2}{*}{$\begin{array}{l}\text { Storage Life } \\
\text { (days) }\end{array}$} & \multirow{2}{*}{$\begin{array}{c}\text { Assessors' } \\
\text { Correct } \\
\text { Responses }\end{array}$} & \multicolumn{3}{|c|}{$1^{\text {st }}$ Replicate } & \multicolumn{3}{|c|}{$2^{\text {nd }}$ Replicate } \\
\hline & & $\begin{array}{c}\mathrm{Zn} \\
\left(\mathrm{T}_{1}\right)\end{array}$ & $\begin{array}{c}\mathrm{Fe} \\
\left(\mathrm{T}_{2}\right)\end{array}$ & $\begin{array}{l}\mathrm{Mg} \\
\left(\mathrm{T}_{3}\right) \\
\end{array}$ & $\begin{array}{c}\mathrm{Zn} \\
\left(\mathrm{T}_{1}\right)\end{array}$ & $\begin{array}{c}\mathrm{Fe} \\
\left(\mathrm{T}_{2}\right)\end{array}$ & $\begin{array}{l}\mathrm{Mg} \\
\left(\mathrm{T}_{3}\right) \\
\end{array}$ \\
\hline \multirow{2}{*}{$\begin{array}{c}\text { At zero } \\
\text { Time }\end{array}$} & Total & 1 & 0 & 2 & 5 & 3 & 5 \\
\hline & Differences & n.s. & n.s. & n.s. & n.s. & n.s. & n.s. \\
\hline \multirow{2}{*}{30} & Total & 1 & 5 & 8 & 7 & 7 & 3 \\
\hline & Differences & n.s. & n.s. & $* *$ & $*$ & $*$ & n.s. \\
\hline \multirow{2}{*}{60} & Total & 5 & 7 & 4 & 8 & 7 & 4 \\
\hline & Differences & n.s. & $*$ & n.s. & $* *$ & $*$ & n.s. \\
\hline
\end{tabular}

${ }^{\mathrm{a}}$ Significance is according to BS ISO (2004) and Meilgaard, et al., (2007)

Table (5): Effect of UHT processing on O.D. and TBARS* at $532 \mathrm{~nm}$ in whole milks fortified with some mineral elements (Mean)**.

\begin{tabular}{|c|c|c|c|c|c|}
\hline \multirow{2}{*}{$\begin{array}{c}\text { Storage } \\
\text { Life } \\
\text { (days) }\end{array}$} & \multirow{2}{*}{$\begin{array}{c}\text { Results } \\
\text { as }\end{array}$} & \multicolumn{4}{|c|}{ UHT milk-fortified with } \\
\cline { 2 - 6 } $\begin{array}{c}\text { At zero } \\
\text { time }\end{array}$ & O.D. & $\begin{array}{c}\text { Control } \\
\left(\mathrm{T}_{0}\right)\end{array}$ & $\begin{array}{c}\text { Zinc } \\
\left(\mathrm{T}_{1}\right)\end{array}$ & $\begin{array}{c}\text { Ferrous } \\
\left(\mathrm{T}_{2}\right)\end{array}$ & $\begin{array}{c}\text { Magnesium } \\
\left(\mathrm{T}_{3}\right)\end{array}$ \\
\cline { 2 - 6 } & TBARS & $0.0063^{\mathrm{b}}$ & $0.0060^{\mathrm{b}}$ & $0.0078^{\mathrm{a}}$ & $0.0068^{\mathrm{ab}}$ \\
\hline \multirow{2}{*}{10} & O.D. & $0.0090^{\mathrm{b}}$ & $0.0563^{\mathrm{b}}$ & $0.0710^{\mathrm{a}}$ & $0.0626^{\mathrm{ab}}$ \\
\cline { 2 - 6 } & TBARS & $0.0815^{\mathrm{b}}$ & $0.0775^{\mathrm{b}}$ & $0.0118^{\mathrm{a}}$ & $0.0100^{\mathrm{b}}$ \\
\hline \multirow{2}{*}{20} & O.D. & $0.0095^{\mathrm{b}}$ & $0.0095^{\mathrm{b}}$ & $0.0120^{\mathrm{a}}$ & $0.0899^{\mathrm{b}}$ \\
\cline { 2 - 6 } & TBARS & $0.0857^{\mathrm{b}}$ & $0.0857^{\mathrm{b}}$ & $0.1067^{\mathrm{a}}$ & $0.0108^{\mathrm{ab}}$ \\
\hline \multirow{2}{*}{30} & O.D. & $0.0098^{\mathrm{b}}$ & $0.0100^{\mathrm{b}}$ & $0.0120^{\mathrm{a}}$ & $0.0122^{\mathrm{a}}$ \\
\cline { 2 - 6 } & TBARS & $0.0878^{\mathrm{b}}$ & $0.0899^{\mathrm{b}}$ & $0.1067^{\mathrm{a}}$ & $0.1067^{\mathrm{a}}$ \\
\hline \multirow{2}{*}{50} & O.D. & $0.0103^{\mathrm{b}}$ & $0.0110^{\mathrm{b}}$ & $0.0130^{\mathrm{a}}$ & $0.0135^{\mathrm{a}}$ \\
\cline { 2 - 6 } & TBARS & $0.0920^{\mathrm{b}}$ & $0.0983^{\mathrm{b}}$ & $0.1151^{\mathrm{a}}$ & $0.1193^{\mathrm{a}}$ \\
\hline & O.D. & $0.0125^{\mathrm{b}}$ & $0.0128^{\mathrm{b}}$ & $0.0170^{\mathrm{a}}$ & $0.0160^{\mathrm{a}}$ \\
\cline { 2 - 6 } & TBARS & $0.1109^{\mathrm{b}}$ & $0.1130^{\mathrm{b}}$ & $0.1487^{\mathrm{a}}$ & $0.1403^{\mathrm{a}}$ \\
\hline \multirow{2}{*}{60} & O.D. & $0.0170^{\mathrm{c}}$ & $0.0163^{\mathrm{c}}$ & $0.0248^{\mathrm{a}}$ & $0.0203^{\mathrm{b}}$ \\
\cline { 2 - 6 } & TBARS & $0.1487^{\mathrm{c}}$ & $0.1424^{\mathrm{c}}$ & $0.2139^{\mathrm{a}}$ & $0.1761^{\mathrm{b}}$ \\
\hline
\end{tabular}

* Thiobarbituric acid reactive substances, calculated from: $\mathrm{y}=0.119 \mathrm{x}-0.0007$

**Figures with different letters horizontally are significant $(\mathrm{p} \leq 0.05)$.

Comparing TBA test results at the end of the storage term with those at d 0 for all treatments (Table 6), all results showed significant increase in TBA values $(p \leq 0.05)$. At $\mathrm{d} 0$ values of OD were $0.0063,0.0060,0.0078$ and 0.0068 for $\mathrm{T}_{0}, \mathrm{~T}_{1}, \mathrm{~T}_{2}$ and $\mathrm{T}_{3}$ respectively. After $60 \mathrm{~d}$ of storage at $30{ }^{\circ} \mathrm{C}$, the values rose to $0.0170,0.0163,0.0248$ and 0.0203 for the same treatments respectively.

The results of both TBA test and sensory evaluation of all milk samples at $\mathrm{d} 0$ were well correlated. TBA values (OD) were not higher than 0.023. And there was not any significant off-flavour perceivable. These results were in agreement with the work of King (1962). Although the TBA values were increasing during the storage term, yet 
the highest value (OD) did not go beyond (0.025) (Table $6 \&$ Figure 1). These results may be attributed to the inhibitory effect of sulfhydryl compounds which develop during heat processing (Shipe et al., 1978).

Table (6): Effect of storage $\left(60 \mathrm{~d} / 30^{\circ} \mathrm{C}\right)$ on O.D. and TBARS at $532 \mathrm{~nm}$ in UHT milks fortified with some mineral elements (Mean)*.

\begin{tabular}{|l|c|c|c|}
\hline \multirow{2}{*}{ Treatments } & $\begin{array}{c}\text { Results } \\
\text { as }\end{array}$ & At zero time & $\begin{array}{c}\text { At the end } \\
\text { of storage life }\end{array}$ \\
\hline \multirow{2}{*}{ Control $\left(\mathrm{T}_{0}\right)$} & O.D. & $0.0063^{\mathrm{a}}$ & $0.0170^{\mathrm{b}}$ \\
\cline { 2 - 4 } & TBARS & $0.0584^{\mathrm{a}}$ & $0.1487^{\mathrm{b}}$ \\
\hline \multirow{2}{*}{ Zinc $\left(\mathrm{T}_{1}\right)$} & O.D. & $0.0060^{\mathrm{a}}$ & $0.0163^{\mathrm{b}}$ \\
\cline { 2 - 4 } & TBARS & $0.0563^{\mathrm{a}}$ & $0.1424^{\mathrm{b}}$ \\
\hline \multirow{2}{*}{ Ferrous $\left(\mathrm{T}_{2}\right)$} & O.D. & $0.0078^{\mathrm{a}}$ & $0.0248^{\mathrm{b}}$ \\
\cline { 2 - 4 } & TBARS & $0.0710^{\mathrm{a}}$ & $0.2138^{\mathrm{b}}$ \\
\hline \multirow{2}{*}{ Magnesium $\left(\mathrm{T}_{3}\right)$} & O.D. & $0.0068^{\mathrm{a}}$ & $0.0203^{\mathrm{b}}$ \\
\cline { 2 - 4 } & TBARS & $0.0626^{\mathrm{a}}$ & $0.1760^{\mathrm{b}}$ \\
\hline
\end{tabular}

* Figures with different letters horizontally are significant $(\mathrm{p} \leq 0.05)$.

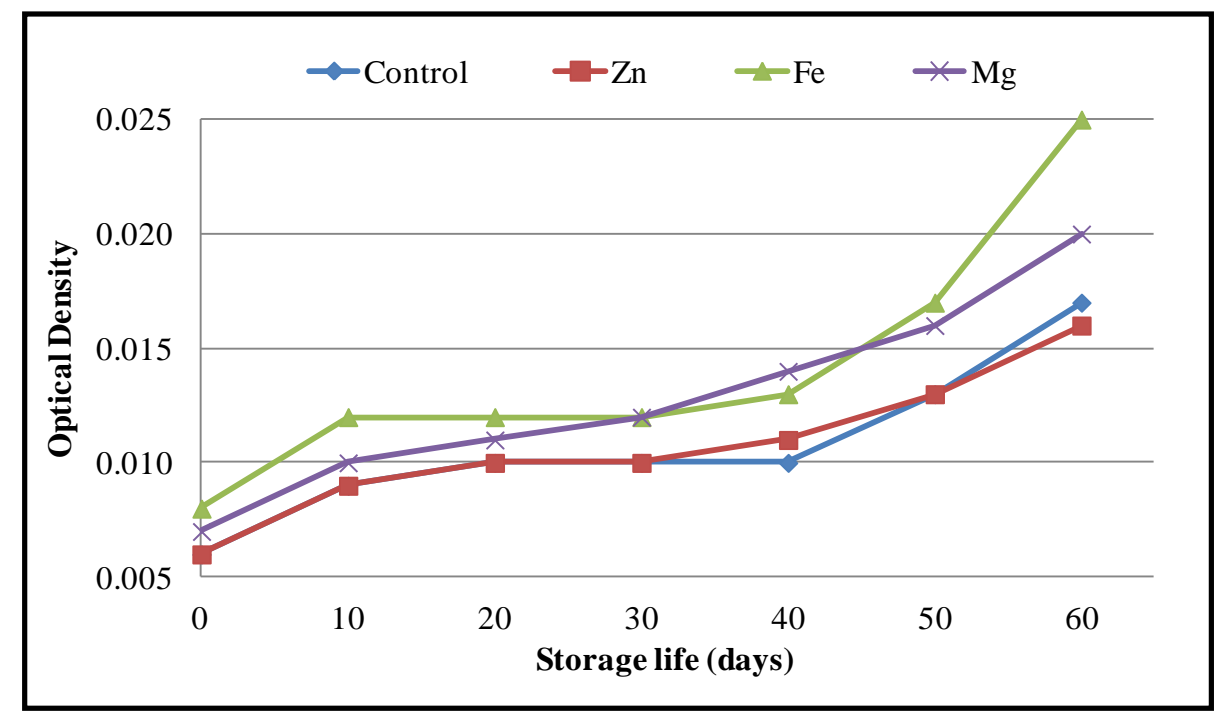

Figure (1): Effect of storage $\left(60 \mathrm{~d} / 30{ }^{\circ} \mathrm{C}\right)$ on the Optical Density of TBA Test at 532 $\mathrm{nm}$ for UHT processed milks fortified with $\mathrm{Zn}, \mathrm{Fe}$ and $\mathrm{Mg}$.

After 60 days of storage, though TBA test value of $\mathrm{T}_{3}$ was 0.0203 (next to highest); the assessors could not perceive the odd samples in both sessions. Samples of $\mathrm{T}_{1}$ were picked up only in the second session while the TBA test value (OD) was only 0.0163 or less than (0.025) which was described by King (1962) as "no oxidized flavour" (Table 3). The alteration in the taste was low, mostly because the milks were stored in dark cabinet. In other words, they did not undergo light activation. The enhancement of the oxidized flavour was only according to free radical mechanism which could be blocked by the sulphur compounds developed during heat processing (Shipe et al., 1978). But, $\mathrm{T}_{2}$ milk showed the highest value of TBA and some 
alteration in milk taste was perceived. Hence, the flavour of the milk-fortified with ferrous $\left(\mathrm{T}_{2}\right)$ could be classified as "questionable to very slight" according to King (1962) (Table 3).

It can be concluded that UHT processing of milk-fortified with $\mathrm{Zn}, \mathrm{Fe}$ and $\mathrm{Mg}$, has no effect on milk taste and the level of the oxidized flavour in comparison with non-fortified UHT milk shortly after processing, but at the end of the storage period, sensory evaluation indicated that only the taste of fortified milk with ferrous could be altered and perceived.

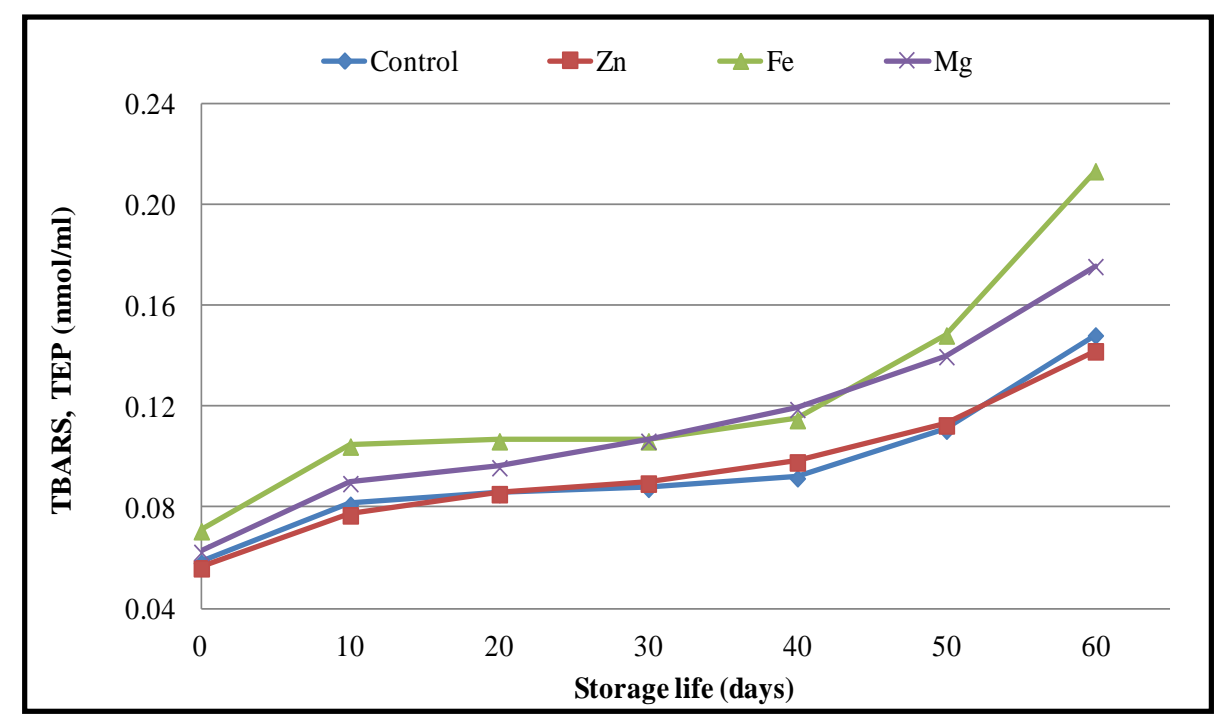

Figure (2): Effect of storage $\left(60 \mathrm{~d} / 30^{\circ} \mathrm{C}\right)$ on the concentration of TBARS (TEP) in UHT processed milks fortified with $\mathrm{Zn}, \mathrm{Fe}$ and $\mathrm{Mg}$.

ACKNOWLEDGEMENT: The authors extend sincere appreciation to Professor Hilton Deeth for his support and are grateful to Sangeeta Prakash, Honest Madziva, Lesleigh Force and Shiou Pang for assistance with the practical lab work. They also thank Olena Kravchuk for her help in statistics.

$$
\text { تأثير المعاملة الحر ارية الفائقة في أكسدة الدهون في الحليب المدعّم ببعض العناصر المعدنية }
$$

E-mail: atallah.abdulghani@yahoo.com

\section{الخلاصة}

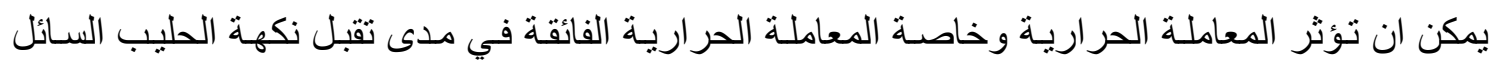

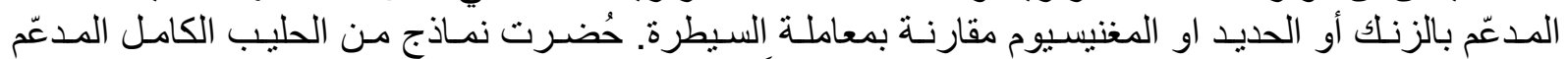

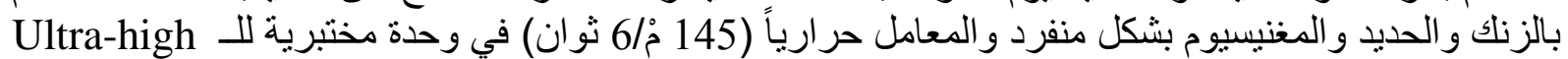

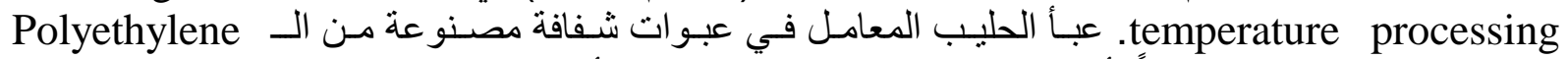
terephthalate

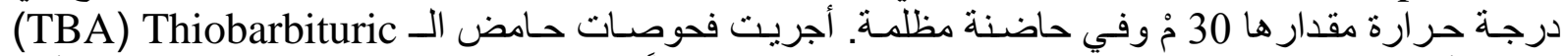
لتقدير تأكسد الدهون واختبار ات مات التقويم الحسي كل 10 و30 يوماً على التو الي. هدف البحث الى دراسـة تأثنير 


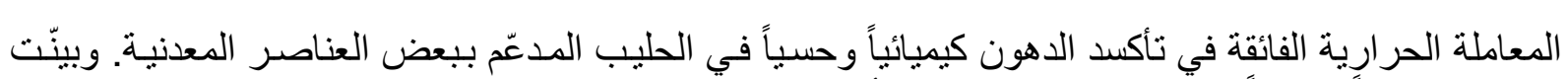

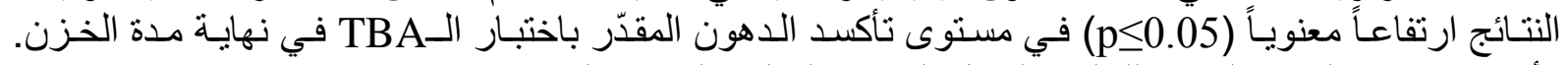

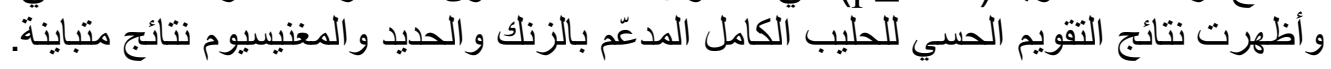

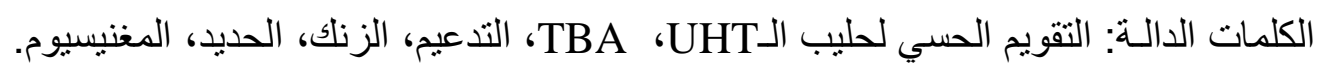
تاريخ نسلم البحث: 2013/3/13 ، وقبوله: 2013/5/6.

\section{REFERENCES}

Anonymous (2002). Statistical Analysis Systems. Software, v. 9, SAS Institute, Cary, NC.

Anonymous (2004). Sensory Analysis-Methodology_-Triangle Test. BS ISO: 4120.

Anonymous (2006). Nutrient Reference Values for Australia and New Zealand including Recommended Dietary Intakes Endorsed by the NHMRC on 9 September 2005. Commonwealth of Australia. ISBN 1864962372.

Choi, I. and I. Jeon (1993). Patterns of fatty acids released from milk fat by residual lipase during storage of ultra-high temperature processed milk. Journal of Dairy Science 76(1):78-85.

Gandy, A., M. Schilling, P. Coggins, C. White, Y. Yoon and V. Kamadia (2008). The effect of pasteurization temperature on consumer acceptability, sensory characteristics, volatile compound composition, and shelf-life of fluid milk. Journal of Dairy Science 91(5): 1769-1777.

Gaucher, I.; D. Mollé; V. Gagnaire and F. Gaucheron (2008). Effects of storage temperature on physico-chemical characteristics of semi-skimmed UHT milk. Food Hydrocolloids 22(1):130-143.

Hayes, W., C. White and M. Drake (2002). Sensory aroma characteristics of milk spoilage by Pseudomonas species. Journal of Food Science 67(1): 448-454.

Hegenauer, J.; P. Saltman; D. Ludwig; L. Ripley and P. Bajo (1979). Effects of supplemental iron and copper on lipid oxidation in milk. 1. Comparison of metal complexes in emulsified and homogenized milk. Journal of Agricultural and Food Chemistry 27(4):860-867.

King, R. (1962). Oxidation of milk fat globule membrane material. I. Thiobarbituric acid reaction as a measure of oxidized flavor in milk and model systems1. Journal of Dairy Science 45(10):1165-1171.

López-Fandiño, R. and A. Olano (1999). Review: Selected indicators of the quality of thermal processed milk. Food Science and Technology International 5(2): 121 137.

Meilgaard, M.; G. Civille and B. Carr (2007). Sensory Evaluation Techniques. CRC, Boca Raton, Florida. CRC Press, Inc. Volume I \& II.

Min, D. and J. Boff (2002). Chemistry and reaction of singlet oxygen in foods. Comprehensive Reviews in Food Science and Food Safety 1(2):58-72.

Muir, D. (1990). The microbiology of heat treated fluid milk products. In: Dairy Microbiology: The Microbiology of Milk, $2^{\text {nd }}$ ed. Edited by R. Robinson. Volume (1):209-243. Elsevier Applied Science, London. 
Perkins, M.; K. Zerdin; M. Rooney; B. D'Arcy and H. Deeth (2007). Active packaging of UHT milk to prevent the development of stale flavour during storage. Packaging Technology and Science 20(2):137-146.

Shipe, W.; R. Bassette; D. Deane; W. Dunkley; E. Hammond; W. Harper; D. Kleyn; M. Morgan; J. Nelson and R. Scanlan (1978). Off flavors of milk: nomenclature, standards, and bibliography. Journal of Dairy Science 61(7): 855-869.

Smet, K.; J. de Block; S. de Campeneere; D. de Brabander; L. Herman; K. Raes; K. Dewettinck and K. Coudijzer (2009). Oxidative stability of UHT milk as influenced by fatty acid composition and packaging. International Dairy Journal 19(6-7):372-379.

Solano-Lopez, C.; T. Ji and V. Alvarez (2005). Volatile compounds and chemical changes in ultrapasteurized milk packaged in polyethylene terephthalate containers. Journal of Food Science 70(6):C407-C412.

Tondo, E.; F. Lakus; F. Oliveira and A. Brandelli (2004). Identification of heat stable protease of Klebsiella oxytoca isolated from raw milk. Letters in Applied Microbiology 38(2):146-150.

Van Aardt, M.; S. Duncan; J. Marcy; T. Long; S. O'Keefe and S. Nielsen-Sims (2005). Effect of antioxidant ( $\alpha$-tocopherol and ascorbic acid) fortification on lightinduced flavor of milk. Journal of Dairy Science 88(3):872-880.

Walstra, P.; J. Wouters and T. Geurts (2006). Dairy Science and Technology. Chapter (2), Milk components. pp. 17-108. CRC Press, Taylor \& Francis Group, Boca Raton, FL. 
Mesopotamia J. of Agric.

Vol. (45) No. (2) 2017
ISSN: 2224 - 9796 (Online)

ISSN: 1815 - 316 X (Print)

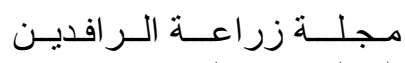

المجلد (45) العدد (2) 2017 